\title{
A New Angular Naphthopyrone from Crinoid Colobometra perspinosa
}

\author{
Hsu-Ming Chung 1*, Ling-Tsung Hsiao ${ }^{1}$, Zong-You Li ${ }^{1,2}$ and \\ Zhi-Hong Wen?2 \\ ${ }^{1}$ Department of Applied Chemistry, National Pingtung University, Pingtung 900391, Taiwan \\ ${ }^{2}$ Department of Marine Biotechnology and Resources, National Sun Yat-sen University, Kaohsiung \\ 804201, Taiwan
}

(Received July 31, 2020; Revised October 12, 2020; Accepted October 16, 2020)

\begin{abstract}
A chemical investigation was carried out on a crinoid Colobometra perspinosa collected from Hengchun Peninsula in the South China Sea, which led to the isolation of five angular naphthopyrones (1-5), including one new metabolite, 8-hydroxy-5,6,10-trimethoxy-2-pentyl-4H-naphtho[1,2-b]pyran-4-one (1). Their structures were assigned based on spectroscopic methods, including UV, HRESIMS, 1D- and 2D-NMR spectra. The anti-inflammatory activity of the isolated compounds was evaluated and compound $\mathbf{5}$ was found to inhibit the accumulation of the pro-inflammatory iNOS protein in LPS-stimulated RAW264.7 macrophages.
\end{abstract}

Keywords: : angular naphthopyrone; crinoid; Colobometra perspinosa; iNOS. @ 2020 ACG Publications. All rights reserved.

\section{Animal Source}

Specimens of $C$. perspinosa were collected in May of 2016 by scuba divers at a depth of 10 $15 \mathrm{~m}$, at the coast of the Hengchun Peninsula in the South China Sea. The specimens were immediately frozen and a voucher specimen (NMMBA-SI-2016-1) was preserved in the National Museum of Marine, Pingtung, Taiwan

\section{Previous Studies}

In the past 50 years, several angular naphthopyrones were isolated from the crinoids of Comantheria perplexa [1], Comantheria rotula [2], Comantheria briareus [3], Comanthus parvicirrus [4-8], as well as an unidentified crinoid of the family Comasteridae [9].

\footnotetext{
*Corresponding author: E-Mail: shiuanmin@mail.nptu.edu.tw 


\section{Present Study}

C. perspinosa (wet/dry weight $=300 / 120 \mathrm{~g}$ ) were sliced and extracted with a mixture of methanol:dichloromethane (1:1). The extract was partitioned between ethyl acetate (EtOAc) and $\mathrm{H}_{2} \mathrm{O}$. The EtOAc layer (2.22 g) was applied on silica gel column and eluted with the gradients solvent of $n$-hexane:EtOAc:acetone (from 100\% $n$-hexane to $100 \%$ acetone) to furnish 15 subfractions. Among them, the sub-fraction 13 was further purified by NP-HPLC, using a solvent mixture of $n$-hexane:acetone:EtOAc (6:4:1) to give compound 1 (3.4 mg) (Figure 1).
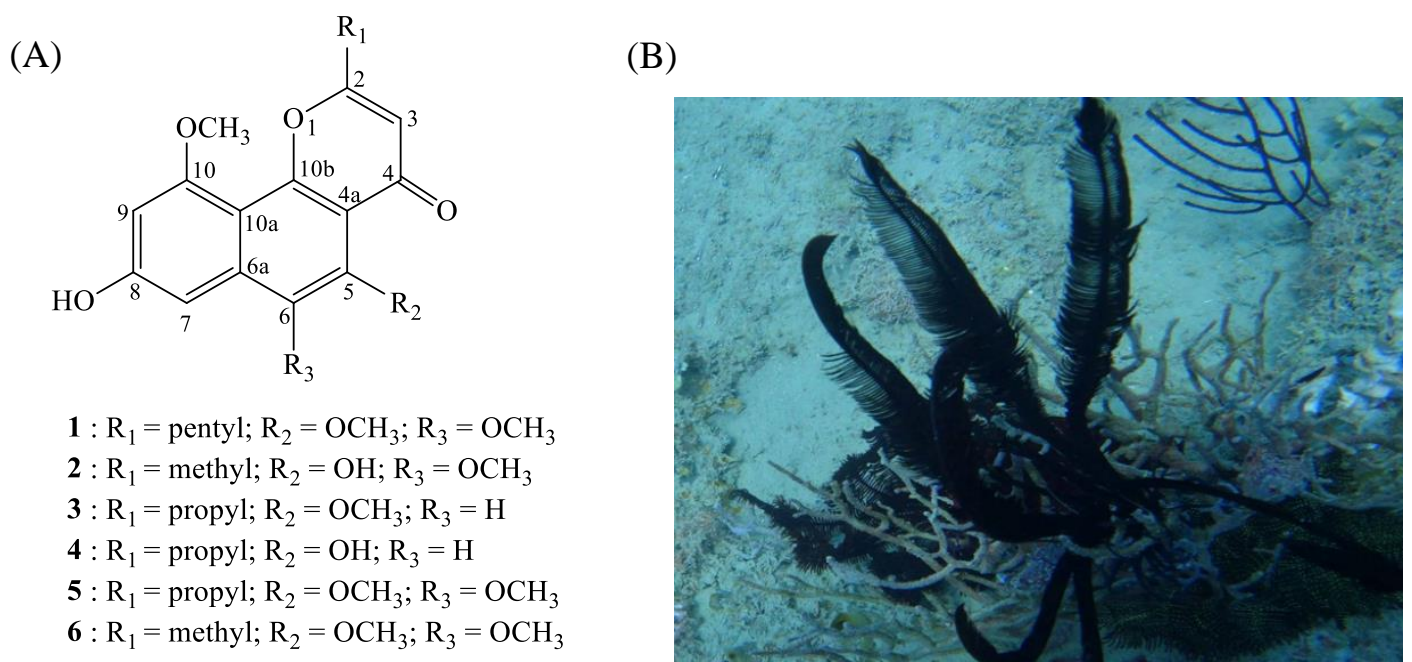

Figure 1. (A) The structures of compounds 1-6; (B) Colobometra perspinosa in its natural habitat

8-Hydroxy-5,6,10-trimethoxy-2-pentyl-4H-naphtho[1,2-b]pyran-4-one (1) was isolated as a green powder that showed a sodiated adduct ion peak at $\mathrm{m} / z$ 395.1465 $(\mathrm{M}+\mathrm{Na})^{+}$in its HRESIMS spectrum, accounted for the molecular formula, $\mathrm{C}_{21} \mathrm{H}_{24} \mathrm{O}_{6}$ (Calcd. for $\mathrm{C}_{21} \mathrm{H}_{24} \mathrm{O}_{6} \mathrm{Na}$, 395.1465) (degrees of unsaturation $=10$ ). The IR spectrum showed absorption bands attributed to hydroxy $\left(3368 \mathrm{~cm}^{-1}\right)$ and $\alpha, \beta$-unsaturated ketonic $\left(1645 \mathrm{~cm}^{-1}\right)$ groups. The ${ }^{13} \mathrm{C}$ NMR and DEPT spectra showed 21 carbon signals including one methyl, four $\mathrm{sp}^{3}$ methylenes, three methoxy groups $\left(\delta_{\mathrm{C}}\right.$ 56.1, C-18; 61.2, C-16; 61.8, C-17), three $\mathrm{sp}^{2}$ methines ( $\left.\delta_{\mathrm{C}} 97.7, \mathrm{C}-7 ; 99.3, \mathrm{C}-9 ; 110.6, \mathrm{C}-3\right)$, and ten quaternary $\mathrm{sp}^{2}$ carbons, one of which was a carbonyl $\left(\delta_{\mathrm{C}} 177.7, \mathrm{C}-4\right)$. The ${ }^{1} \mathrm{H}$ NMR spectrum showed signals for one singlet methyl $\left(\delta_{\mathrm{H}} 0.92,3 \mathrm{H}, \mathrm{t}, J=7.5 \mathrm{~Hz}, \mathrm{H}_{3}-15\right)$, four pairs of methylene protons $\left(\delta_{\mathrm{H}}\right.$ $1.38,2 \mathrm{H}, \mathrm{m}, \mathrm{H}_{2}-14 ; 1.41,2 \mathrm{H}, \mathrm{m}, \mathrm{H}_{2}-13 ; 1.85,2 \mathrm{H}, \mathrm{td}, J=15.0,7.5 \mathrm{~Hz}, \mathrm{H}_{2}-12 ; 2.72,2 \mathrm{H}, \mathrm{t}, J=7.5 \mathrm{~Hz}$, $\left.\mathrm{H}_{2}-11\right)$, three methoxy groups $\left(\delta_{\mathrm{H}} 3.93,3 \mathrm{H}, \mathrm{s}, \mathrm{H}_{3}-16 ; 3.98,3 \mathrm{H}, \mathrm{s}, \mathrm{H}_{3}-17 ; 4.00,3 \mathrm{H}, \mathrm{s}, \mathrm{H}_{3}-18\right)$, and three aromatic protons $\left(\delta_{\mathrm{H}} 6.49,1 \mathrm{H}, \mathrm{s}, \mathrm{H}-3 ; 6.78,1 \mathrm{H}, \mathrm{d}, J=2.5 \mathrm{~Hz}, \mathrm{H}-9 ; 7.20,1 \mathrm{H}, \mathrm{d}, J=2.5 \mathrm{~Hz}, \mathrm{H}-\right.$ 7), which were observed in the ${ }^{1} \mathrm{H}$ NMR spectrum (Table 1). The structural units of 1 were determined using the COSY spectrum, then two separated coupling systems of $\mathrm{H}-7 / \mathrm{H}-9$ (by meta coupling) and $\mathrm{H}_{2}-11 / \mathrm{H}_{2}-12 / \mathrm{H}_{2}-13 / \mathrm{H}_{2}-14 / \mathrm{H}_{3}-15$ were subsequently identified. The HMBC correlation between the methoxy group resonances at $\mathrm{H}_{3}-16 / \mathrm{C}-5 ; \mathrm{H}_{3}-17 / \mathrm{C}-6 ; \mathrm{H}_{3}-18 / \mathrm{C}-10$, and $\mathrm{H}-7 / \mathrm{C}-6, \mathrm{C}-6 \mathrm{a}, \mathrm{C}-$ 8, C-9; H-9/C-7, C-8, C-10 established the presence of the methoxy group at the aromatic rings. The presence of a pentyl group on C-2 was supported by the HMBC correlation between $\mathrm{H}-3 / \mathrm{C}-2, \mathrm{C}-11$, and $\mathrm{H}_{2}-11 / \mathrm{C}-2, \mathrm{C}-3$ (Figure 2). The UV differences between the linear and angular naphthopyrones are well documented and the absorptions at 238, 273, and $361 \mathrm{~nm}$ of $\mathbf{1}$ indicated an angular naphthopyrone [4]. 
Table 1. ${ }^{1} \mathrm{H}$ and ${ }^{13} \mathrm{C}$ NMR data for compound $\mathbf{1}$

\begin{tabular}{ccc}
\hline Position & $\boldsymbol{\delta}_{\mathbf{H}^{\mathbf{a}}}$ & $\boldsymbol{\delta} \mathbf{c}^{\mathbf{b}}$ type \\
\hline 2 & & $168.3, \mathrm{C}^{\mathrm{c}}$ \\
3 & $6.49 \mathrm{~s}$ & $110.6, \mathrm{CH}$ \\
4 & & $177.7, \mathrm{C}$ \\
$4 \mathrm{a}$ & & $113.3, \mathrm{C}$ \\
5 & & $145.9, \mathrm{C}$ \\
6 & & $143.8, \mathrm{C}$ \\
$6 \mathrm{a}$ & & $159.5, \mathrm{C}$ \\
7 & $7.20 \mathrm{~d}(2.5)$ & $97.7, \mathrm{CH}$ \\
8 & & $107.7, \mathrm{C}$ \\
9 & $6.78 \mathrm{~d}(2.5)$ & $99.3, \mathrm{CH}$ \\
10 & & $159.9, \mathrm{C}$ \\
$10 \mathrm{a}$ & & $135.4, \mathrm{C}$ \\
$10 \mathrm{~b}$ & & $154.0, \mathrm{C}$ \\
11 & $2.72 \mathrm{t}(7.5)$ & $34.0, \mathrm{CH}_{2}$ \\
12 & $1.85 \mathrm{td}(7.5,15.0)$ & $26.1, \mathrm{CH}_{2}$ \\
13 & $1.41 \mathrm{~m}$ & $31.1, \mathrm{CH}_{2}$ \\
14 & $1.38 \mathrm{~m}$ & $22.4, \mathrm{CH}_{2}$ \\
15 & $0.92 \mathrm{t}(7.5)$ & $13.9, \mathrm{CH}_{3}$ \\
16 & $3.96 \mathrm{~s}$ & $61.2, \mathrm{CH}_{3}$ \\
17 & $3.98 \mathrm{~s}$ & $61.8, \mathrm{CH}_{3}$ \\
18 & $4.00 \mathrm{~s}$ & $56.1, \mathrm{CH}_{3}$ \\
\hline
\end{tabular}

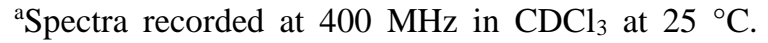

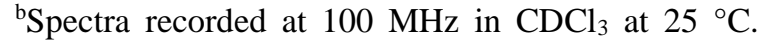

${ }^{\mathrm{c}}$ Multiplicity deduced by DEPT spectra.

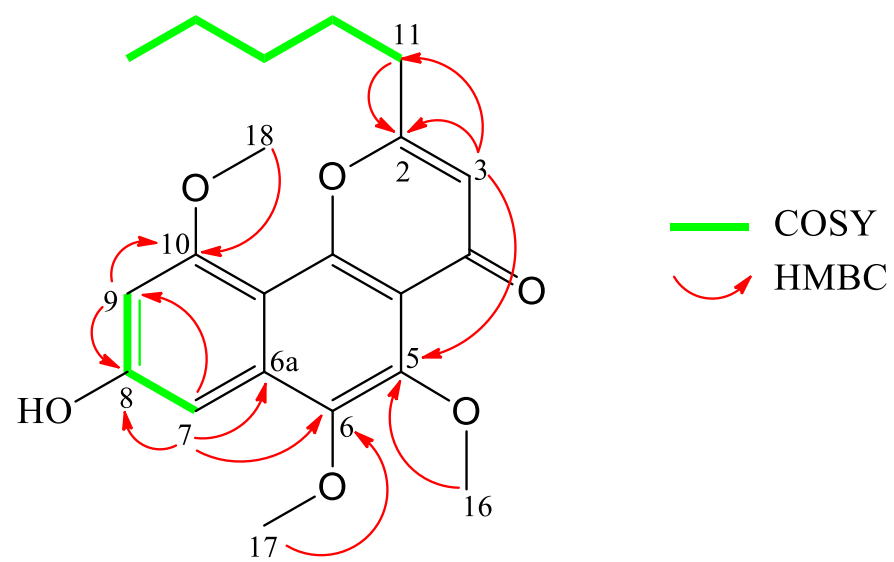

Figure 2. The ${ }^{1} \mathrm{H}-{ }^{1} \mathrm{H}-\mathrm{COSY}$ and $\mathrm{HMBC}$ correlations for $\mathbf{1}$

The previously studied ${ }^{13} \mathrm{C}$ NMR were similar to the angular naphthopyrone aromatic ring of compound 1 (Table 2) [8-9]. The known compounds 2-5 were identified as compound 2 [9], compound 3 [9], comaparvin [4], and 6-methoxycomaparvin-5-methyl ether [8] by comparing their spectroscopic data with the reported literature. Angular naphthopyrones commonly possess a methyl and a propyl group at the $\mathrm{C}-2$ position. Compound $\mathbf{1}$ is the first identified compound with a pentyl group at $\mathrm{C}-2$. 
Table 2. Key ${ }^{13} \mathrm{C}$ NMR data for compounds $\mathbf{1}, \mathbf{5}$, and $\mathbf{6}$

\begin{tabular}{|c|c|c|c|}
\hline & 1 & 5 & 6 \\
\hline Position & $\delta_{\mathrm{C}}^{\mathrm{a}}$, type & $\delta_{\mathrm{C}^{\mathrm{b}}}^{\mathrm{b}}$, type & $\delta_{\mathrm{C}^{\mathrm{c}}}^{\mathrm{c}}$ \\
\hline $4 a$ & $113.3, \mathrm{C}$ & 114.6, C & 113.3 \\
\hline 5 & $145,9, \mathrm{C}$ & $146.9, \mathrm{C}$ & 146.0 \\
\hline 6 & $143.8, \mathrm{C}$ & 135.2, C & 142.6 \\
\hline $6 a$ & $159.5, \mathrm{C}$ & $158.0, \mathrm{C}$ & 134.2 \\
\hline 7 & $97.7, \mathrm{CH}$ & $97.4, \mathrm{CH}$ & 96.3 \\
\hline 8 & 107.7, C & $108.4, \mathrm{C}$ & 159.7 \\
\hline 9 & $99.3, \mathrm{CH}$ & $99.0, \mathrm{CH}$ & 99.6 \\
\hline 10 & $159.9, \mathrm{C}$ & $160.1, \mathrm{C}$ & 159.3 \\
\hline $10 \mathrm{a}$ & $135.4, \mathrm{C}$ & $143.6, \mathrm{C}$ & 106.6 \\
\hline $10 \mathrm{~b}$ & $154.0, \mathrm{C}$ & $153.0, \mathrm{C}$ & 152.7 \\
\hline
\end{tabular}

${ }^{\text {a Spectra recorded at } 125 \mathrm{MHz} \text { in } \mathrm{CDCl}_{3} \text { at } 25{ }^{\circ} \mathrm{C} \text {. }{ }^{\mathrm{b}} \mathrm{Spectra} \text { recorded at } 100 \mathrm{M}} \mathrm{Hz}$ in $\mathrm{CDCl}_{3}$ [8]. ${ }^{\mathrm{c}}$ Spectra recorded at $125 \mathrm{MHz}$ in DMSO- $d_{6}$ [9].

The in vitro anti-inflammatory activities of compounds 1-5 were measured by examining the inhibition of LPS (lipopolysaccharide) induced upregulation of iNOS (inducible nitric oxide synthetase) and COX-2 (cyclooxygenase-2) proteins in macrophages using Western blotting analysis. RAW264.7 cells were obtained from the American Type Culture Collection (ATCC TIB-71, Manassas, VA, USA) [10]. In comparison with the cells stimulated with LPS alone, the group of macrophages treated with $\mathbf{5}(10 \mu \mathrm{M})$ showed that compound $\mathbf{5}$ exhibited a potent anti-inflammatory effect with $83.74 \%$ iNOS inhibition (Figure 3 and Table 3 ).
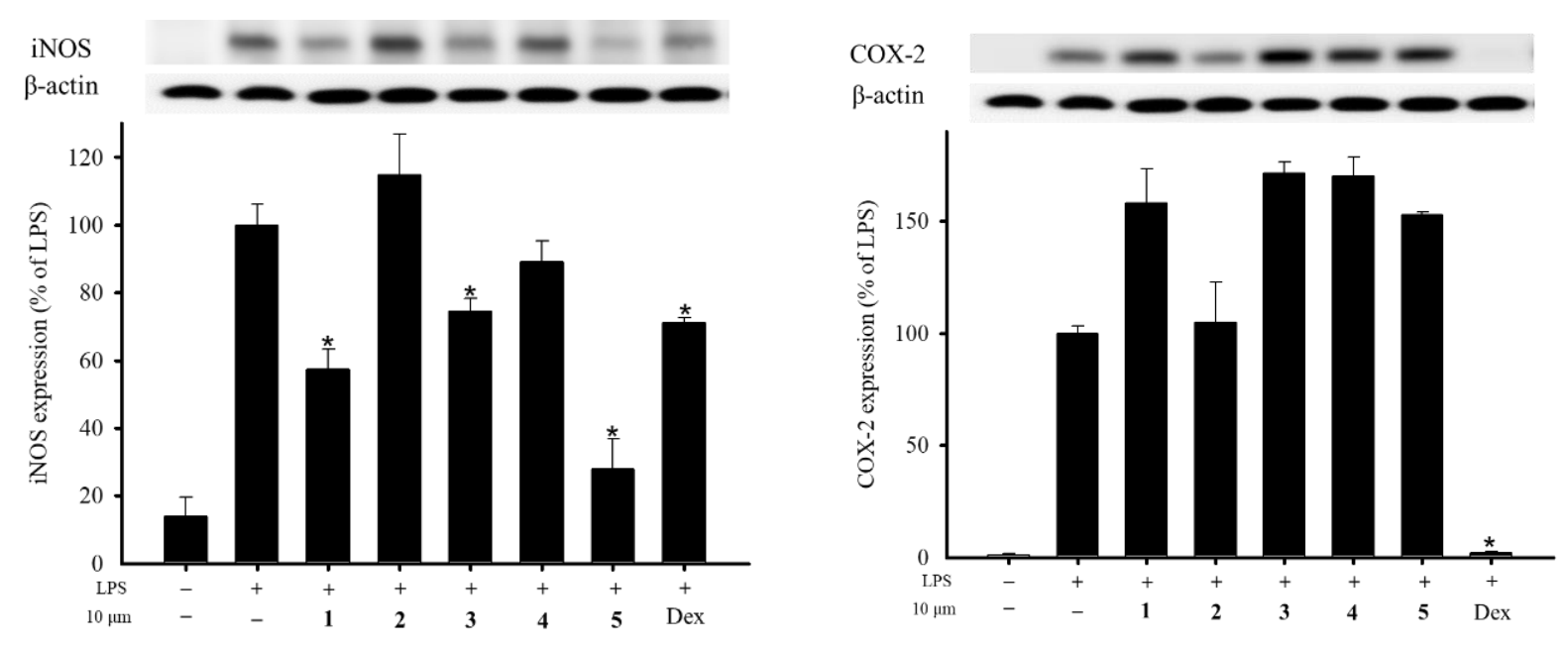

Figure 3. Effect of compounds 1-5 $(10 \mu \mathrm{M})$ on pro-inflammatory iNOS and COX-2 protein expressions in the LPS-stimulated murine macrophage cell line RAW264.7 by Western blotting analysis. Data were normalized to those of cells treated with LPS alone, and the cells treated with dexamethasone $(10 \mu \mathrm{M})$ were used as a positive control. Data are expressed as the mean $\pm \mathrm{SEM}$ $(\mathrm{n}=3)$. Significantly different from the cells treated with LPS $(p<0.05)$. 
Table 3. Effects of compounds 1-5 on LPS-induced iNOS and COX-2 protein expressions in macrophages

\begin{tabular}{lccc}
\hline & iNOS & COX-2 & $\boldsymbol{\beta}$-actin \\
\hline Control & $13.96 \pm 5.76$ & $1.06 \pm 1.16$ & $105.75 \pm 4.03$ \\
LPS & $100.00 \pm 6.09$ & $100.00 \pm 5.86$ & $100.00 \pm 0.50$ \\
$\mathbf{1}$ & $57.26 \pm 6.14$ & $158.19 \pm 26.29$ & $124.13 \pm 7.01$ \\
$\mathbf{2}$ & $114.87 \pm 11.95$ & $104.80 \pm 31.14$ & $117.88 \pm 12.39$ \\
$\mathbf{3}$ & $74.59 \pm 3.68$ & $171.37 \pm 8.76$ & $127.43 \pm 4.49$ \\
$\mathbf{4}$ & $89.16 \pm 6.06$ & $170.09 \pm 14.63$ & $120.17 \pm 16.76$ \\
$\mathbf{5}$ & $27.95 \pm 8.75$ & $152.81 \pm 2.13$ & $103.67 \pm 18.26$ \\
Dex $^{\mathrm{a}}$ & $71.13 \pm 1.39$ & $2.22 \pm 0.69$ & $130.04 \pm 8.07$ \\
\hline
\end{tabular}

${ }^{a}$ Dexamethasone (DEX, $\left.10 \mu \mathrm{M}\right)$ was used as a positive control.

\section{Acknowledgments}

We thank Dr. Ping-Jyun Sung for providing the samples. This research was supported by the grants from the National Pingtung University; and the Ministry of Science and Technology, Taiwan (Grant Nos: MOST 107-2320-B-153 -001) awarded to Hsu-Ming Chung.

\section{Supporting Information}

Supporting Information accompanies this paper on http://www.acgpubs.org/journal/recordsof-natural-products

\section{ORCID}

Hsu-Ming Chung: 0000-0003-1472-9268

Ling-Tsung Hsiao: 0000-0003-4486-2035

Zong-You Li: 0000-0002-7849-1909

Zhi-Hong Wen: 0000-0003-4411-044X

\section{References}

[1] R. A. Kent, I. R. Smith and M. D. Sutherland (1970). Pigments of marine animals. X. Substituted naphthopyrones from the crinoid Comantheria perplexa, Aust. J. Chem. 23, 2325-2335.

[2] J. Dai, Y. Liu, H. Jia, Y.D. Zhou and D. G. Nagle (2007). Benzochromenones from the marine crinoid Comantheria rotula inhibit hypoxia-inducible factor-1 (HIF-1) in cell-based reporter assays and differentially suppress the growth of certain tumor cell lines, J. Nat. Prod. 70, 1462-1466.

[3] A. K. Francesconi (1980). Pigments of some echinoderms collected from Western Australian waters, Aust. J. Chem. 33, 2781-2784.

[4] I. R. Smith and M. D. Sutherland (1971). Pigments of marine animals. XI. angular naphthopyrones from the crinoid Comanthus parvicirrus timorensis, Aust. J. Chem. 24, 1487-1499.

[5] J. A. Rideout, I. R. Smith and M. D. Sutherland (1976). Pigments of marine animals. XII. The synthesis of certain substituted naphthopyrones related to crinoid pigments, Aust. J. Chem. 29, 10871098.

[6] J. A. Rideout, I. R. Smith and M. D. Sutherland (1979). Chemical defense of crinoids by polyketide sulphates, Aust. J. Chem. 35, 1273-1274.

[7] Y. Sakuma, J. Tanaka and T. Higa (1987). New naphthopyrone pigments from the crinoid Comanthus parvicirrus, Aust. J. Chem. 40, 1613-1616. 
[8] F. Folmer, W. T. A. Harrison, J. N. Tabudravu, M. Jaspars, W. Aalbersberg, K. Feussner, A. D. Wright, M. Dicato and M. Diederich (2008). NF-кB-inhibiting naphthopyrones from the Fijian echinoderm Comanthus parvicirrus, J. Nat. Prod. 71, 106-111.

[9] H. R. Bokesch, L. K. Cartner, R. W. Fuller, J. A. Wilson, C. J. Henrich, J. A. Kelley, K. R. Gustafson, J. B. McMahon and T. C. Mckee (2010). Inhibition of ABCG2-mediated drug efflux by naphthopyrones from marine crinoids, Bioorg. Med. Chem. Lett. 20, 3848-3850.

[10] Y. Y. Lin, S. C. Lin, C. W. Feng, P. C. Chen, Y. D. Su, C. M. Li, S. N. Yang, Y. H. Jean, P. J. Sung, C. Y. Duh and Z. H. Wen (2015). Anti-inflammatory and analgesic effects of the marine-derived compound excavatolide B isolated from the culture-type formosan Gorgonian Briareum excavatum, Mar. Drugs 13, 2559-2579.

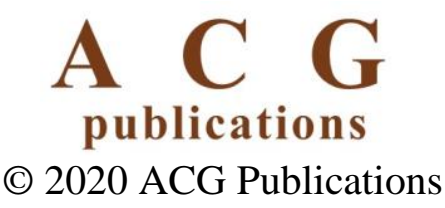

